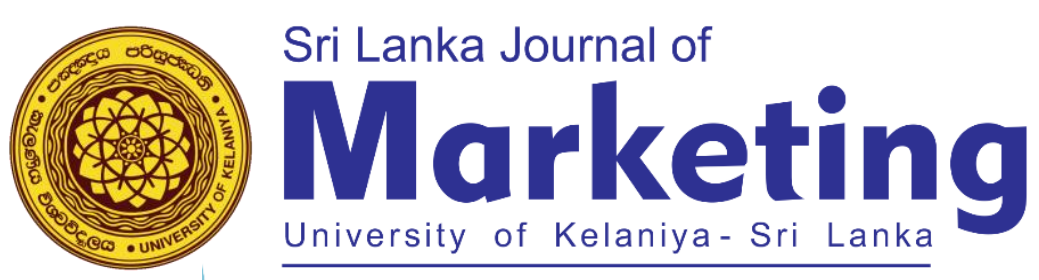

\title{
Factors influencing the Purchase Intention of Green Packaging among Millennials in Gampaha District of Sri Lanka
}

\author{
Munasinghe P. M. \\ Department of Economics and Statistics, Sabaragamuwa University of Sri Lanka \\ pavi.m.munasinghe@gmail.com \\ Shantha A. A. \\ Department of Economics and Statistics, Sabaragamuwa University of Sri Lanka \\ arunaeconomics999@gmail.com
}

\section{ABSTRACT}

Fast moving consumer goods sector is one of the expanding industries that influences on the green marketing issues. This study seeks to understand how the impact of green packaging on consumer purchasing intention among millennial generation in Gampaha District. The main objective is "to identify the factors that mostly influence on millennial consumer's green packaging purchase intention". According to comprehensive literature review, the researcher identified 4 variables of purchase intention namely; Product Characteristics, Environmental Concern, Government Role and Demographic Factors. Further, researcher was able to recognize the most enhancing components for some independent variables. Then, examined the hypothesis by using PLS-SEM except the Demographic Factors. Therefore, Education, Income and Gender under demographic variables tested chi-square test, Pearson correlation and significances by using SPSS. The researcher distributed questionnaires randomly to selected sample of 200 respondents selected under the multi stage sampling method according to a proportion within the 8 GN Divisions out of 37 in Kelaniya DS Division in Gampaha District who age between 18 - 35 years. All examined variables determined positive relationship with Purchasing Intention except Gender. However, the outcomes represented that no significant effect of Government Role, Environmental Concern, Income, Gender and Investment of Government under the Government Role but other mentioned variables recorded 95\% significant on Purchasing Intention. The study identified that younger generation has an awareness and knowledge about ecological behavior. The implications of this study formed awareness into buying intention towards ecological packaging which can be used by FMCG businesses in Sri Lanka when deigning product packages.

Keywords: Demographic Factors, Environmental Concern, Government is Role, Product Characteristics, Purchase Intention 


\section{INTRODUCTION}

\subsection{Background and Research Problem}

Nowadays the feeling about to be "eco - friendly" or "green" has grown in a massive way. Many companies are trying to promote their products by labeling their goods in the name of eco friendliness. Therefore, consumers are becoming more sensitive in their purchasing behaviors according to the environmental sensitivity. Environmental aware is a customer behavior or attitudes that is comely to be worldwide in the period of changes in the impression of customer behavior or attitudes. Consumer who are knowledgeable of and interests in ecological problems are called "green consumer". Ottman (2003) identified that customers obtained eco production when their primary need for performance, quality of product, convenience and also economically were met and when they understood how an ecological product could help to solve the ecological problems.

Green marketing is a worldwide and broad concept in the world, which is a collection of small subject areas in the society. Green marketing attempt to emphasize consumers' purchase intention (Chen and Chang, 2012). Since the 1980s green marketing has gone through various level, after a comeback in the 1980s green marketing has made a boom in the west from 2000 onwards (Ottman, Stafford and Hartman, 2006). Green marketing is a major concept appear in the latter half of the $20^{\text {th }}$ century which is developed through the environment attitudes (Peattie \& Crane, 2005). However, there are five reasons for businesses to develop eco-friendly marketing concept: conformity with ecological pressure, improving corporate images, achieving competitive advantage, go for new markets or opportunities and increasing product value (Chen, Lai and Wen ,2006). Even though Asian consumers have currently become one of the primary targets for international green marketers due to the following reasons: consumers in Asian societies are increasingly becoming aware to the scaring environmental problems (Harris, 2006); and the fast-growing economies in Asia has cause to strongly of financially - allowed consumers across Asia who are willing to spend more than former generations ( $\mathrm{Li}$ and $\mathrm{Su}, 2007$ ).

Environmental issues influence on all most all activities in day today lives, then FMCG sector is a significantly huge market in the economy which has to open their attention on eco friendliness to the world (Wanninayake and Randiwela, 2008). FMCG have a high-income level and short life time, increasing amount of packages will remain as waste. FMCG marketing businesses in Sri Lanka use ecofriendly and recyclable packaging and adjust the products to decrease or disallow the environment pollution. According to Chen and Chai, 2010 suggested that investigated how people view the environmental problems and how they behave of that, especially in their attitudes among ecological production or environmental friendly products. There is a world respect approach for waste management, which is " $3 \mathrm{R}$ Model" then under that model ecological packages can do in three unique ways; Reuse, Recycle and Reduce. 
Green packaging industry is progressively expanding over the countries which resulting establishment for businesses who can occur with newly innovative ideas in green packaging at a minimum costly way. However, two main functions achieved by the principles of 4R ID, there are Reduce, Reuse, Reclaim, Recycle and Degradable (Zhang and Zhao, 2012). According to Global Web Index (2018) identified that who are age between 16-21 are more like to pay 58\% and age between $22-35$ are able to pay $61 \%$ for the eco-friendly production. The global green packaging market size is recorded to reach $\$ 207.5$ billion by 2022 with a combined annual expansion rate of 5.41\% between 2016 and 2022 (Global Green Packaging Market Analysis, 2018). Sometimes it might be there are some barriers of their consumption style, negative perceptions, Low availability, Distrust of green claims and Lack of awareness of eco friendly productions etc. (Bonini and Oppenheim, 2008).

Every Businesses are to generate profit while assuring their stakeholders, and also achieving to their goals and objectives of firm, they have to consider various factors relating to customers, environment and products etc. The problem is to find out the real motivation and also most influencing factors behind on the customers purchasing behaviors. Nowadays FMCG sector in the Sri Lanka move to ecological friendly way with some specific modifications. According to Ottman \& Reilly (1998) identified that $41 \%$ of customers do not move to purchase ecological products because of distinguish between their life behaviors and attitudes. Nowadays, purchasing intention is more puzzling and more significant for customers than in the past because of that more attention of the society, more and more businesses are able to accept the ecological responsibility. Ecological products are one of the responses to concern for the environment.

Chan and Yam (1995) examined that an individual's environmental behavior is highly dependent on her/his ecological affect, knowledge and intention. Therefore, customers are becoming more sensitivity to their environmental attitudes, purchases and preferences. Chen and Chai (2010) explored how customers view the environmental problems and how they behave, exclusively in their view regards eco products or environmental friendly products. According to Straughan \& Roberts (1999) reported younger were likely to be more sensitive to environmental problems through ecological behaviors. Green purchasing behavior positively correlation among age, income and gender with significantly (Soonthonsmai, 2001). Most of studies focused on the importance of demographic factors like education, income, gender and also age how to affect to the green purchasing intention. Jolibert and Baumgartner (1981) found that green customer was younger and more educated their ecological attitudes was not income related. Higher level of subjective knowledge about ecological behavior were related with higher income but there was no relationship between higher level of greener knowledge and individuals' age, education and gender (Amyx, Denjong, Chakraorty and Wiener, 1994).

According to the Sri Lankan context, The FMCG sector is very influential as its great involvement in the economy besides the familiarity to Sri Lankan customers' life pattern. Nowadays Sri Lankan FMCG 
marketing firm's application ecological friendly and biodegradable packaging and also adjust the products to reduce or avoid the environment pollution. Therefore, some researchers identified that ecological products gain some addition value to the consumers and economy in a developing country like Sri Lanka (Samarasinghe.G.D. \& Samarasinghe.D.S.R.,2013). Wanninayake and Randiwela (2008), reported that eco-friendly products have considerable responsiveness between Sri Lankan customers and also, they are willing to consume something more on ecological products. Under that investigated researcher recognized that the packages are most considerable element rather than others concerning from ecological products. The environmental knowledge and ecological buying behaviors are significantly influence to the economy and perceptions of consumers in Sri Lanka (Samarasinghe.G. D \& Samarasinghe. D.S.R., 2013).

Although, this research identified that single consumers have more strongly positive behavior with ecological products than married consumers in Sri Lanka. Because of that, single people have more freedom from their buying decision and more disposable income to consume eco-friendly products in Sri Lanka. Further, that research is also exposed that when considering the gender, Sri Lankan females have more ecological buying behaviors than males. So that it may be caused by their emotional response and also understanding among environment. According to the Wanninayake and Randiwela (2008), suggested that demographic variables have not any significant relationship with ecological buying intention in Sri Lanka. However, Sri Lankan consumers are more willing to purchase and already have good knowledge about green products than past decades. Since there are limited studies conducted within Sri Lankan context. Then this study identified which factors are highly correlate with green buying behaviors among Sri Lankan millennial consumers.

According to this study mainly focuses on the impact of green packaging on millennial consumer purchasing intention. Many researchers argued that environmental friendly production concern with regard to green marketing concept but this study impact of green behaviors consider only under the Fast-Moving Consumer Good sector. Although many of studies focused on whole country to their investigations and do not selected any age limit in the society to the study, however few of researches try to examined under the green purchasing decision and ecological attitudes with regards to special age group. When we are considering different age group in the society under the green behaviors, then results are varied from one age group to other. However, in this research, the main focus will be the FMCG industry and also purchasing behavior for green packaging of millennial generation in 2002 1985 (Age between 18 and 35 years) in Gampaha District, Sri Lanka. Finally, the problem which is going to address through this study is; "The extent the factors are influencing on consumer purchase intention towards products with green packaging, with special reference to millennial customers in Gampaha District”. 
The main objective of this study is to identify the factors that have the most impact on the millennial consumer's intention to purchase green packaging. The specific objectives are; (a) to determine the terms of influence made by determinants on purchase intention towards green packages (b) to find out the customer awareness on green packaging and (c) to identify the demographic factors like education, income and gender how to affect to the ecological purchasing intention.

\section{LITERATURE REVIEW}

"Going green" are now extending to the Asian region, then adopt a green lifestyle people need to make certain changes in their day to day life. Green marketing activities are increasing in many countries and these activities have had a significant influence on increment of customer knowledge of green behavior and in shifting customer into buying more ecological products. Ecological packaging is helped in the sustainability of the country. Environmental friendly packaging is a recent phenomenon which has become a rapidly growing trend. Organizations can move to green materials or green packaging, then can achieve consumers' higher level of demands for eco-friendly suppliers. The literature survey has helped to the developed the theoretical framework and hypotheses for all the variables for testing.

\subsection{Product Characteristics}

Some people do not able to trade off other products attributes for a better environmental, so that the characteristics of traditional goods and services like as the price, quality and brand are still the most important variables that are regarded by customers about green buying opinion (Gan, 2008). Price is one of the major elements of purchasing decisions and also focusing on product price, opinion is the most dependable describing factor in predicting customers' desire to pay for green products (Chyong, Phang, Hasan and Buncha,2006). D’Souza, Taghian and Khosla (2007), recommended that the confidence on the part of customers whom extended eco production should be ecologically safe and prospect without a need to offering on green product quality and price levels. According to Laroche, Bergeron and Barbaro-Forleo (2001), reported that most of consumers will have to purchase ecological products but at a reasonable price levels and having quality for this consumer wants to be higher educated.

There is increasing evidence among product characteristics and ecological packaging under the green purchasing intention. According to Rayapura (2014), identified that global online customer in sixty countries around the international level, then studied expressed willingness to pay more for ecological goods and services from businesses that are indicated to positive impact on the socially and environmentally. According to D'Souza et al., (2007) reported that when the environmentally friendly products have higher prices and low quality then it affects to the negative concern with the consumer purchasing intention and consumer ecological attitudes. 
H 1: There is significant relationship between product characteristics on consumer purchase intention towards Green Packaging.

H 1a: There is a significant relationship between prices on product characteristics towards Green Packaging purchasing Intention.

$\boldsymbol{H} \mathbf{1}_{b}$ : There is a significant relationship between qualities on product characteristics towards Green Packaging purchasing Intention.

\subsection{Environmental Concern}

Environmental concern is one of most important factors when selecting a product with the green package over another. The responsibility of the customers, recycling and reuse level of customers and environmental knowledge can be identified under the environmental concern. "Environmental concern is rooted in a person's concept of self and the degree to which an individual perceives him or herself to be an integral part of the natural environment" (Schultz and Zelezny, 2000). Ecological products or green behaviors, products with appropriately encouraging of non -biodegradable garbage or recyclable packaging, customers can provide remarkably to improve the environment quality level of the economy (Abdul- Muhmin, 2007). Environmental knowledge as "a general knowledge of facts, concepts and relationships concerning the natural environment and its major ecosystem" (Fryxell and Lo, 2003). Most of studies reported the how to effect on environmental concern on the preference of products like organic food products (Hoffmann and Schlicht, 2013) washing powders (Kinnear and Taylor, 1973), inexhaustible power (Bang, Ellinger, Hadjimarcou and Traichal, 2000) and cosmetics and toiletries (Ottman, 2003). Environmental attentiveness has been ranked as one of the most special forecasters of appropriate environmental behavior (Grob, 1995).

According to Irawan and Darmayanti (2012), reported that the ecological concern has a significant impact on ecological purchasing behaviors among Indonesian university students and also this study mainly focused on green buying behaviors with young generation and also consider the impact on education level to the purchasing behaviors. Some studies explored that general attitudes and behaviors about eco-products are analytical indirect elements of specific behaviors, as well as ecological concern has no any direct influence on consumer behavior but it is having an instant effect on the consumer perceptions (Bamberg, 2012; Roberts and Bacon, 1997). However sufficient advance education will affect to positive impact on motivation of purchasing level and humans waste handling behaviors in Malaysian consumers (Zen, Noor and Yusuf, 2014).

H 2: There is significant relationship between Environmental Concern of the Customers on Purchase Intention towards Green Packaging. 
$\boldsymbol{H} 2_{a}:$ There is a significant relationship between responsibilities of the consumers on environmental concern towards Green Packaging purchasing Intention.

$\boldsymbol{H} 2_{b}$ : There is a significant relationship between recycling \& reuse level of the consumer on environmental concern towards Green Packaging purchasing Intention.

$\boldsymbol{H} 2_{c}$ : There is a significant relationship between environmental knowledge on environmental concern towards Green Packaging purchasing Intention.

\subsection{Government Role}

Government should play the guiding role of the management, through the development of policies and regulations or use economical instruments like tax, subsidies to limit or encourage the production level of designing and processing green packaging behaviors. According to Chukwuma (1998) the most significant variables influencing nature was not the official government policy but the public realization on the green behaviors or ecological problems. Kaman (2008) imply that organizational strategies and government policies and regulatory framework in many Asian countries are being reestablishment to give more attention to huge sustainable development including environmental protection behaviors and increasing social efficiency. Government have to play the managing role of management, throughout the sustainability of regulation and policies or apply the economic indicators to limit of corrigible manufacturers use in production level and processing of packaging in orderly ecological packaging (Zhang and Zhao, 2012). According to Lehner, Popwer and Mont (2011) state that the function of regulations has maintaining and forwarding environmental behavior Regulatory, Economic, Information and Behavioral are four main dimensions of regulation - tool that can be used to encouragement of the environmental behaviors.

According to find out of Pavan (2010), the government have to increase public recognition about environmentally friendly products and also ecological labels by carrying our public attack. In Chicago also consider this situation Rothsten (2011), explored that the especially the quality of government indicators have positive correlation with three local environmental quality indicators. The suggestion of ecological regulations has direct positive outcome with the increasing rules of law (Fredriksson, Per and Mani, 2002). Another study in Dummett (2006), identified that government rules and regulations have become the more powerful and significant correlation on the eco businesses attitudes and ecological manners.

\section{H 3: There is a significant relationship between Roles of the Government on Consumer Purchase} Intention towards Green Packaging. 
$\boldsymbol{H} \mathbf{3}_{a}$ : There is a significant relationship between investments on government's role towards Green Packaging purchasing Intention.

$\boldsymbol{H} 3_{b}$ : There is a significant relationship between establishing rules \& regulations on government's role towards Green Packaging purchasing Intention.

\subsection{Demographic Factors}

Many studies show that the willingness of customers to purchase eco-friendly products is highly related to demographics. According to Makeower (2009) identified that values, knowledge, beliefs, motivation, attitudes and demographics as mainly affected that influence the customer willing to purchase green products especially green packaging section. Dettmann and Dimithri (2007), defined that customers with higher education were more focused in buying ecological food than those with less education. However, Roberts (1996) found that gender had mainly influence on environmental behaviors and also, he identified that females were more likely to buy green products than males but Eagly (1987), identified that male having more negative attitudes than female under the environmental friendly opinions. According to Straughau and Roberts (1999), studied high school students based upon environmentally behaviors and identified that the younger individuals were more likely to be highly sensitive to environmental problems and the demographic variables like gender, age were more significantly with purchasing behaviors.

Chen and chai (2010), recognized that there were no gender differences in ecological behavior among Malaysian consumers. However dominant forms of femininity and masculinity are displayed as each other's opposites, which means that if males do one thing than females do the contrary one to that (Eagly, 1987: Roberts, 1996). Dettmann and Dimithri (2007) identified that women with age 30-45 with children having high disposable income through their income level include ecological behaviors in their purchasing pattern. Soonthonsmai, (2001) impels that income level correlates positively with ecological buying behaviors except for education level. So high income level can influence to high buying behaviors because of that eco-products are more expensive than regular customary products (Follows, Scott and David, 2000).

\section{H 4: There is a relationship between Education, Income and Gender under the Demographic Factors on Consumer Purchase Intention towards Green Packaging.}

H 4a: There is a significant relationship between education on demographic factors towards Green Packaging purchasing Intention.

$\boldsymbol{H} 4_{b}$ : There is a significant relationship between income on demographic factors towards Green Packaging purchasing Intention. 
$\boldsymbol{H} 4_{c}$ : There is a significant relationship between gender on demographic factors towards Green Packaging purchasing Intention.

\section{METHODOLOGY}

The aim of this research study is to studies the relationships between green packaging and consumer ecological purchasing intention of millennial generation in Gampaha District, Sri Lanka. This study indicating the relationship between the green packaging on Product Characteristics, Environmental Concern, Government Role and Demographic Factors of green buying behaviors on younger consumers. The particular information describes the predictable significant relationship among the variables and also it occurs at the final target, the entire research approaches must be rationalized by validating the correct study approach and methodology of this study.

\subsection{Operationalization}

Table 1: Operationalization

\begin{tabular}{|c|c|c|c|c|}
\hline Variables & $\begin{array}{l}\text { Measurement } \\
\text { Indicators }\end{array}$ & Indicators & Sources & Measurement \\
\hline \multirow[b]{2}{*}{$\begin{array}{c}\text { Product } \\
\text { Characteristi } \\
\text { cs }\end{array}$} & Price & $\begin{array}{l}\text { - } \begin{array}{l}\text { Organizations have to } \\
\text { charge higher price. }\end{array} \\
\text { - It is acceptable to pay } \\
\text { some amount for products } \\
\text { - Feel about production cost } \\
\text { with conventionally } \\
\text { packaged } \\
\text { - Willing to spend more } \\
\text { money to buying eco } \\
\text { products }\end{array}$ & \multirow{2}{*}{$\begin{array}{l}\text { Gan (2008), } \\
\text { Ahmed, Parmar } \\
\text { and Amin } \\
(2014), \\
\text { Paul \& Rana } \\
\text { (2012), Oakland } \\
\text { \& Porter (2004) }\end{array}$} & \multirow{2}{*}{$\begin{aligned} 5 \text { Points } & \text { Likert Scale } \\
1- & \text { Strongly } \\
& \text { Disagree } \\
2- & \text { Disagree } \\
3- & \text { Neither Agree or } \\
& \text { Disagree } \\
4- & \text { Agree } \\
5- & \text { Strongly Agree }\end{aligned}$} \\
\hline & Quality & 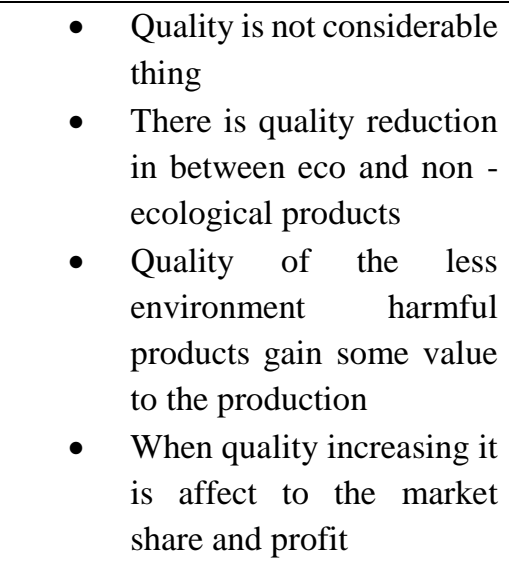 & & \\
\hline $\begin{array}{c}\text { Environment } \\
\text { al Concern }\end{array}$ & $\begin{array}{c}\text { Responsibility } \\
\text { of the } \\
\text { Consumers }\end{array}$ & $\begin{array}{l}\text { - } \begin{array}{l}\text { Environmental protection } \\
\text { begins with me }\end{array} \\
\text { - Already taken responsibility } \\
\text { for save environment. }\end{array}$ & $\begin{array}{l}\text { Jain \& Kaur } \\
\text { (2004), Kalafatis, } \\
\text { Pollard, East, \& } \\
\text { Tsogas (1999), }\end{array}$ & $\begin{aligned} & 5 \text { Points Likert Scale } \\
& 1-\quad \text { Strongly } \\
& \text { Disagree } \\
& \text { 2- } \text { Disagree }\end{aligned}$ \\
\hline
\end{tabular}




\begin{tabular}{|c|c|c|c|c|}
\hline & & $\begin{array}{l}\text { - Mankind was created to rule } \\
\text { over the rest of nature } \\
\text { - Should do what I can to } \\
\text { conserve environmental } \\
\text { resources }\end{array}$ & $\begin{array}{l}\text { Yeung (2004), } \\
\text { Mansaray and } \\
\text { Abijoye (1998), }\end{array}$ & $\begin{array}{ll}\text { 3- } & \text { Neither Agree or } \\
& \text { Disagree } \\
\text { 4- } & \text { Agree } \\
\text { 5- } & \text { Strongly Agree }\end{array}$ \\
\hline & $\begin{array}{c}\text { Recycling and } \\
\text { Reuse levels } \\
\text { of Consumers }\end{array}$ & $\begin{array}{l}\text { - Hope to purchase the products } \\
\text { with reusable packages } \\
\text { - } \\
\text { Plan to buy the products with } \\
\text { recyclable materials } \\
\text { Make special effort to purchase } \\
\text { eco products which I have } \\
\text { switched products for } \\
\text { ecological reasons. } \\
\text { Recycling and recusing gain } \\
\text { some value to the eco products }\end{array}$ & & \\
\hline & $\begin{array}{c}\text { Environmental } \\
\text { Knowledge }\end{array}$ & $\begin{array}{l}\text { - Have very good knowledge } \\
\text { about environmental issues. } \\
\text { - Understand the environmental } \\
\text { tags and signs on product } \\
\text { packages } \\
\text { - Hope to buy less harmful to } \\
\text { others and the environment } \\
\text { - Use to improve my knowledge } \\
\text { about ecological manner by } \\
\text { using social medias, daily } \\
\text { newspapers and mass medias. }\end{array}$ & & \\
\hline \multirow[t]{2}{*}{$\begin{array}{c}\text { Government } \\
\text { Role }\end{array}$} & Investments & $\begin{array}{l}\text { - Government should subsidies } \\
\text { research on technology for } \\
\text { recycling waste products. } \\
\text { - Schools should essential to add } \\
\text { a subject to make students } \\
\text { - Environmental awareness } \\
\text { programs are conducted to } \\
\text { protect the environment } \\
\text { Social advertisements on } \\
\text { environmental protection and } \\
\text { its benefits to the society are } \\
\text { promoted via mass medias, } \\
\text { social networks and } \\
\text { newspapers by government. }\end{array}$ & \multirow{2}{*}{$\begin{array}{l}\text { Wood (1991), } \\
\text { Peck \& Gibson, } \\
\text { (2000), } \\
\text { Polonsky (1994), } \\
\text { Mani \& } \\
\text { Fredriksson } \\
\text { (2002) }\end{array}$} & \multirow[t]{2}{*}{$\begin{aligned} & 5 \text { Points Likert Scale } \\
& 1- \text { Strongly } \\
& \text { Disagree } \\
& 2- \text { Disagree } \\
& 3- \text { Neither Agree or } \\
& \text { Disagree } \\
& 4- \text { Agree } \\
& 5- \text { Strongly Agree }\end{aligned}$} \\
\hline & $\begin{array}{l}\text { Establishing } \\
\text { Rules \& } \\
\text { Regulations }\end{array}$ & 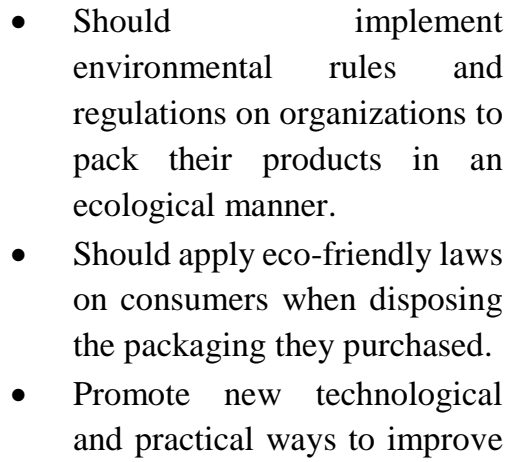 & & \\
\hline
\end{tabular}




\begin{tabular}{|c|c|c|c|c|}
\hline & & $\begin{array}{l}\text { the ecological production } \\
\text { patterns } \\
\text { - Should establish specific } \\
\text { emission level to the } \\
\text { environment and implement } \\
\text { tax system }\end{array}$ & & \\
\hline \multirow{3}{*}{$\begin{array}{c}\text { Demographi } \\
\text { c Factors }\end{array}$} & Education & $\begin{array}{l}\text { Education has higher } \\
\text { sensitivity to social problems } \\
\text { and environmental behaviors }\end{array}$ & \multirow{3}{*}{$\begin{array}{l}\text { Anderson and } \\
\text { Cunninghanm } \\
\text { (1972), } \\
\text { Powell and } \\
\text { Graves (2003), } \\
\text { Chen and Chai } \\
\text { (2010), } \\
\text { Xiao and Hong } \\
\text { (2010), } \\
\text { Mahmoud, } \\
\text { Mojtaba, Reza, } \\
\text { Roozben, Omid } \\
\text { and Dariush } \\
\text { (2011) }\end{array}$} & $\begin{array}{ll}\text { Categorical Data } \\
\begin{aligned} \text { 1. } & \text { Below Grade } 10 \\
\text { 2. } & \mathrm{O} / \mathrm{L} \\
\text { 3. } & \mathrm{A} / \mathrm{L} \\
\text { 4. } & \text { Undergraduate } \\
\text { 5. } & \text { Graduate } \\
\text { 6. } & \text { Masters }\end{aligned}\end{array}$ \\
\hline & Income & $\begin{array}{l}\text { - Consumer with middle income } \\
\text { group and upper - middle } \\
\text { income level group also } \\
\text { integration to those customers } \\
\text { who give more attention to } \\
\text { environmental perceptions and } \\
\text { behaviors }\end{array}$ & & 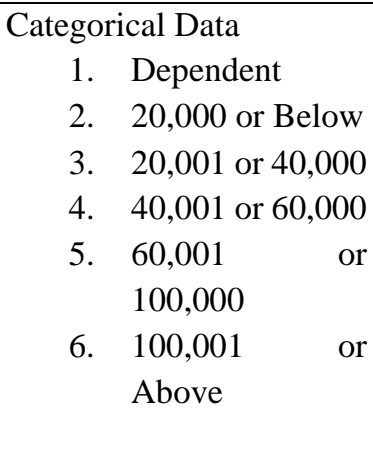 \\
\hline & Gender & $\begin{array}{l}\text { - Male tends to use activities to } \\
\text { establish status and respect } \\
\text { whereas females tend to use } \\
\text { activities to express harmony } \\
\text { and equality. }\end{array}$ & & $\begin{array}{l}\text { Categorical Data } \\
\text { 1. Male } \\
\text { 2. } \text { Female }\end{array}$ \\
\hline $\begin{array}{l}\text { Purchasing } \\
\text { Intention }\end{array}$ & & $\begin{array}{l}\text { - Like to purchase products with } \\
\text { an eco-friendly packaging. } \\
\text { Hope to move to products with } \\
\text { an environmentally friendly } \\
\text { package. } \\
\text { Consider purchasing } \\
\text { ecological packaged products } \\
\text { because that cause to less } \\
\text { pollution. } \\
\text { Consider switching to other } \\
\text { brands from my current } \\
\text { favourite brand for ecological } \\
\text { reasons }\end{array}$ & $\begin{array}{l}\text { Mostafa (2007), } \\
\text { Keller (2001), } \\
\text { Chan (2001) }\end{array}$ & $\begin{aligned} 5 \text { Points } & \text { Likert Scale } \\
1- & \text { Strongly } \\
& \text { Disagree } \\
2- & \text { Disagree } \\
3- & \text { Neither Agree or } \\
& \text { Disagree } \\
4- & \text { Agree } \\
5- & \text { Strongly Agree }\end{aligned}$ \\
\hline
\end{tabular}

\subsection{Research Site}

This research data gathered from millennial generation in 2002 - 1985 (Age between 18 - 35 years) because of this study mainly focused to identify how youngers are more likely to consume FMCG and their behavior about the green products. The Multistage cluster sampling method was used to select 
participants for the study because of that it is a type of sampling which involves dividing the population into groups. The researcher randomly selects some specific survey area to finding the sample through the selected Kelaniya DS Division out of 13 DS Divisions in Gampaha District. The total population is in Kelaniya DS Division recorded in 134,693 (Department of Census and Statistics, 2019) in 37 GN Divisions. Out of these 37 GN Divisions in this research select only 8 GN Divisions to the survey.

Figure1: Sample Proportion

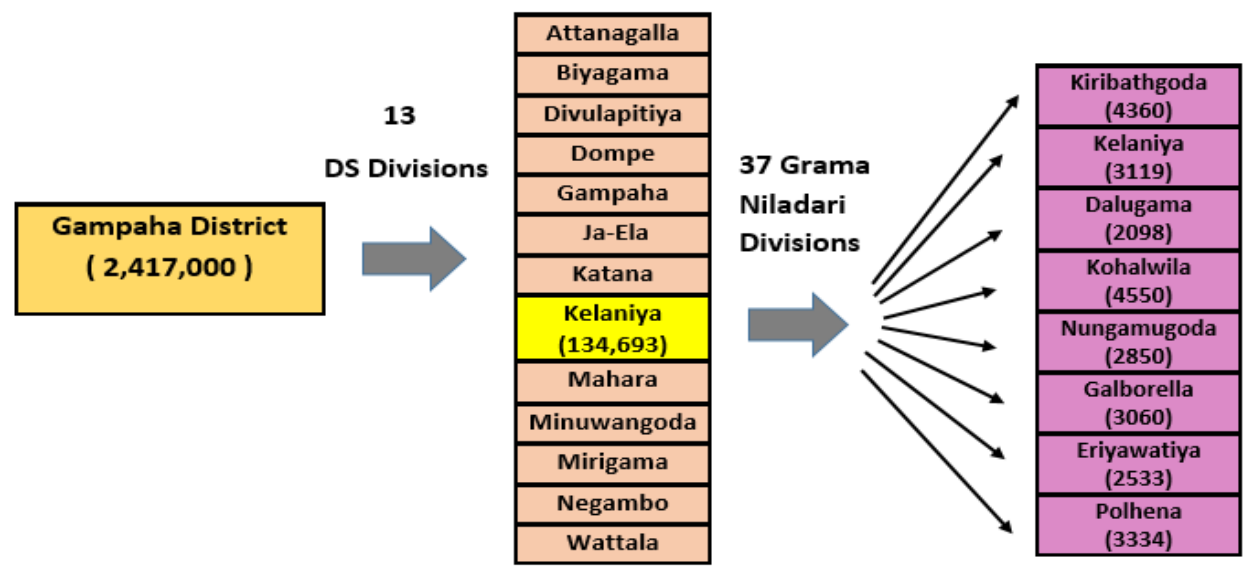

Source: Department of Census and Statistics, 2019

\subsection{Population}

In this study, the population include of both male and female age between 18 and 35 years who reside within the Kelaniya Divisional Secretary Division in Gampaha District. This population representing the Millennial Generation in Kelaniya DS Division in Gampaha District out of 13 DS Divisions. The total population is in Kelaniya DS Division in Gampaha District recorded in 134,693. (Department of Census and Statistics, 2019). Out of that 37 Grama Niladhari Divisions this research selects only 8 GN Divisions to the survey. All these 8 GN Divisions have 25,904 total populations. Further the research will be based on the Fast-Moving Consumer Good (FMCG) industry. For this study millennial consumers can be recognized as who born in 1985 -2002 years.

\subsection{Sample}

In this study the sample of 200 respondents will be select within the Kelaniya DS Division in Gampaha District who are age between 18 - 35 years that means who born in 1985- 2002 years. According to the Morgan table, the sample was 378 under the selected population, but this study used only 200 sample to collected the data because of the current social situation as well as the considered the cost and time period. This survey conducted in 8 GN Divisions in Kelaniya DS Division. Then specific area chosen by under the multi stage sampling method according to a proportion out of 200 sample selection criteria. The structured questionnaire distributed by using selected proportionate sample size in the specific GN Divisions in Kelaniya DS Division. Especially under that sample size, one household represent the one 
respondent only in this study to identify the how to impact of green packaging on consumer buying among younger generation. The researcher took the following sample of respondents from each area.

Table 1: Sample selection

\begin{tabular}{|c|c|c|c|}
\hline \multicolumn{4}{|c|}{ Kelaniya DS Division - Total Population 134,693 in 37 GNs. } \\
\hline & Grama Niladari Division & Population & Sample \\
\hline $258 \mathrm{~B}-$ & Nungamugoda & 2850 & 22 \\
\hline $259 \mathrm{~B}-$ & Kohalwila & 4550 & 35 \\
\hline $259 \mathrm{C}-$ & Eriyawatiya & 2533 & 20 \\
\hline $260 \mathrm{~A}-$ & Dalugama & 2098 & 16 \\
\hline $261 \mathrm{~A}-$ & Galborella & 3060 & 24 \\
\hline $264-$ & Kelaniya & 3119 & 24 \\
\hline $264 \mathrm{~A}-$ & Polhena & 3334 & 25 \\
\hline $267 \mathrm{~A}-$ & Kiribathgoda & 4360 & 34 \\
\hline & Total & 25,904 & 200 \\
\hline
\end{tabular}

Source: Survey Findings, 2020

\subsection{Method of Analyzing}

Figure 2: Hypothesis testing under the conceptual frame work

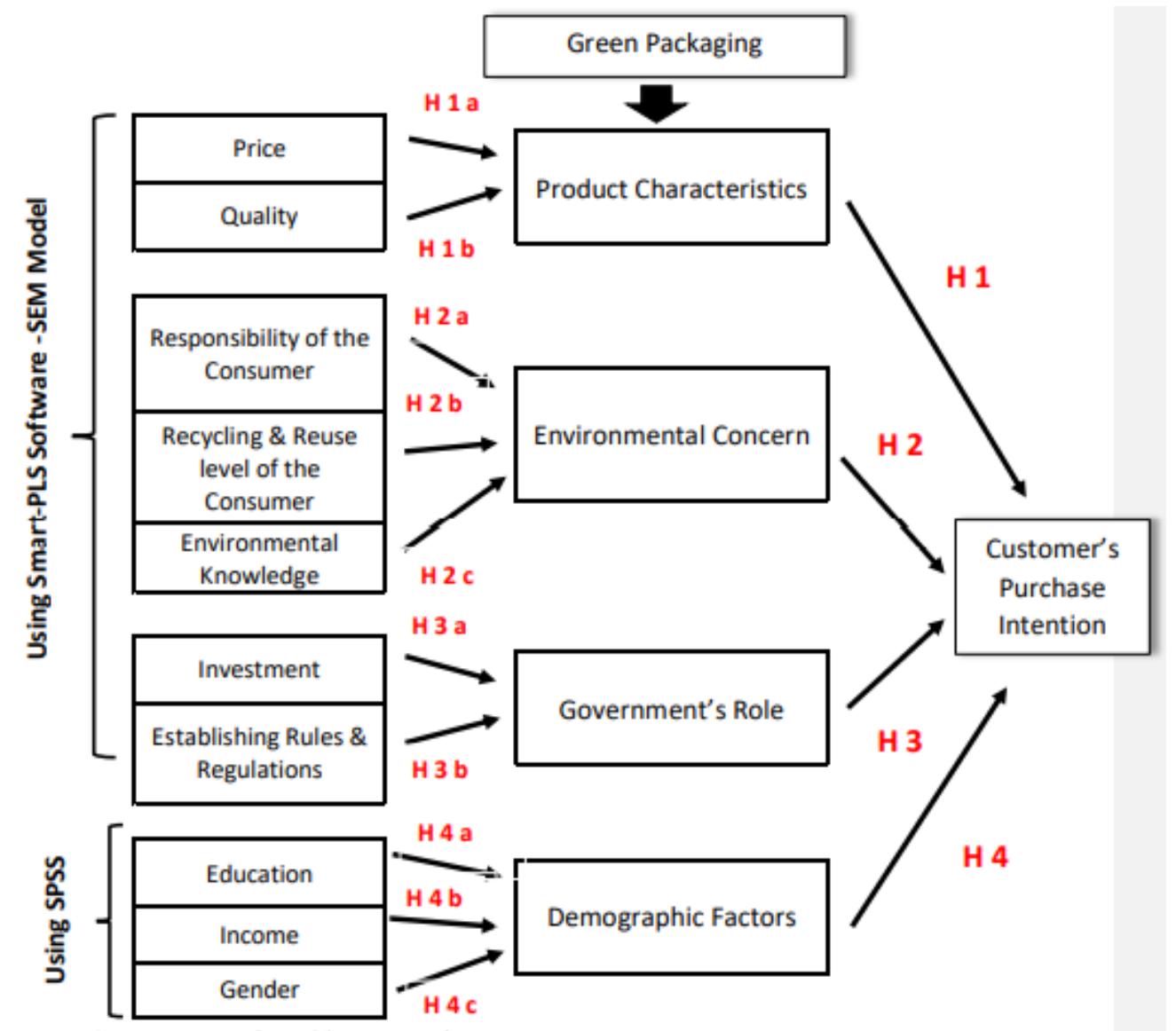

Source: Developed by researcher 


\section{DATA ANALYSIS}

\subsection{Measurement Model (Outer Model)}

Before testing the consistency of the structural model, the outer model was tested for construct reliability and validity of the measurement model using the survey data. This assessment would be done under two steps; First order analysis and the Second order analysis. Initially under first order analysis reliability and validity scores between questionnaire items with indicator variables were generated. Afterwards, under second order analysis validity and reliability scores between indicators and variables were calculated.

\subsection{First order analysis}

Table 3: Validity and Reliability Constructs of First Order Analysis

\begin{tabular}{|c|c|c|c|c|c|}
\hline \multirow{2}{*}{ Construct } & \multicolumn{2}{|c|}{ Indicator Reliability } & \multirow{2}{*}{$\begin{array}{c}\text { Internal Reliability } \\
\text { Composite } \\
\text { Reliability }\end{array}$} & \multirow{2}{*}{$\begin{array}{c}\text { Consistency } \\
\text { Cronbach's } \\
\text { Alpha }\end{array}$} & \multirow{2}{*}{$\begin{array}{c}\begin{array}{c}\text { Convergen } \\
\text { Validity }\end{array} \\
\text { AVE }\end{array}$} \\
\hline & Loadings & t-Statistic & & & \\
\hline \multicolumn{6}{|c|}{ Product Characteristics } \\
\hline Price & & & \multirow{4}{*}{0.950893} & \multirow{4}{*}{0.922487} & \multirow{4}{*}{0.865877} \\
\hline Q1 & 0.917593 & 44.574223 & & & \\
\hline Q2 & 0.948008 & 79.391844 & & & \\
\hline Q3 & 0.925707 & 50.910595 & & & \\
\hline Quality & & & \multirow{5}{*}{0.959573} & \multirow{5}{*}{0.943672} & \multirow{5}{*}{0.855846} \\
\hline Q1 & 0.893723 & 41.656553 & & & \\
\hline $\mathbf{Q 2}$ & 0.941130 & 66.536718 & & & \\
\hline Q3 & 0.947279 & 82.259914 & & & \\
\hline Q4 & 0.917377 & 52.716554 & & & \\
\hline \multicolumn{6}{|c|}{ Environmental Concern } \\
\hline $\begin{array}{l}\text { Responsibility o } \\
\text { the Consumer }\end{array}$ & & & \multirow{5}{*}{0.970488} & \multirow{5}{*}{0.959093} & \multirow{5}{*}{0.891669} \\
\hline Q1 & 0.897971 & 36.834834 & & & \\
\hline Q2 & 0.974864 & $\begin{array}{c}169.49484 \\
2\end{array}$ & & & \\
\hline Q3 & 0.927150 & 73.322634 & & & \\
\hline Q4 & 0.944864 & $\begin{array}{c}139.49488 \\
2\end{array}$ & & & \\
\hline \multicolumn{3}{|c|}{$\begin{array}{c}\text { Recycling \& } \\
\text { Reuse level of the } \\
\text { Consumer }\end{array}$} & \multirow{3}{*}{0.965126} & \multirow{3}{*}{0.927792} & \multirow{3}{*}{0.932602} \\
\hline Q1 & 0.967729 & $\begin{array}{c}157.57485 \\
5\end{array}$ & & & \\
\hline Q2 & 0.963694 & $\begin{array}{c}114.24531 \\
7 \\
\end{array}$ & & & \\
\hline \multicolumn{3}{|l|}{$\begin{array}{c}\text { Environmental } \\
\text { Knowledge }\end{array}$} & \multirow{3}{*}{0.852094} & \multirow{3}{*}{0.653886} & \multirow{3}{*}{0.742372} \\
\hline Q1 & 0.877840 & 5.712404 & & & \\
\hline Q2 & 0.845069 & 4.653651 & & & \\
\hline \multicolumn{6}{|c|}{ Government's Role } \\
\hline Investment & & & \multirow{2}{*}{0.912045} & \multirow{2}{*}{0.855413} & \multirow{2}{*}{0.775825} \\
\hline Q1 & 0.916155 & 7.030737 & & & \\
\hline
\end{tabular}




\begin{tabular}{|c|c|c|c|c|c|}
\hline Q2 & 0.840164 & 6.495808 & & \\
\hline Q3 & 0.884455 & 6.909024 & & \\
\hline $\begin{array}{c}\text { Establishing } \\
\text { Rules \& } \\
\text { Regulations }\end{array}$ & \multicolumn{2}{|c|}{} & & \\
\hline Q2 & 0.921095 & 47.434533 & 0.955693 & 0.930399 & 0.877923 \\
\hline Q3 & 0.954418 & 89.316049 & & \\
\hline Q4 & 0.935115 & 67.669996 & & \\
\hline
\end{tabular}

Source: Survey Data, 2020

\subsection{Second order analysis}

Table 4: Validity and Reliability Constructs of Second Order Analysis

\begin{tabular}{|c|c|c|c|c|c|}
\hline \multirow{2}{*}{ Construct } & \multicolumn{2}{|c|}{ Indicator Reliability } & \multirow{2}{*}{$\begin{array}{c}\text { Internal Reliability } \\
\text { Composite } \\
\text { Reliability }\end{array}$} & \multirow{2}{*}{$\begin{array}{c}\text { Consistency } \\
\text { Cronbach's } \\
\text { Alpha }\end{array}$} & \multirow{2}{*}{$\begin{array}{c}\begin{array}{c}\text { Convergent } \\
\text { Validity }\end{array} \\
\text { AVE }\end{array}$} \\
\hline & Loadings & t-Statistic & & & \\
\hline \multicolumn{6}{|c|}{ Product Characteristics } \\
\hline Price & & & \multirow{4}{*}{0.950893} & \multirow{4}{*}{0.922487} & \multirow{4}{*}{0.865877} \\
\hline Q1 & 0.917593 & 44.574223 & & & \\
\hline Q2 & 0.948008 & 79.391844 & & & \\
\hline Q3 & 0.925707 & 50.910595 & & & \\
\hline Quality & & & \multirow{5}{*}{0.959573} & \multirow{5}{*}{0.943672} & \multirow{5}{*}{0.855846} \\
\hline Q1 & 0.893723 & 41.656553 & & & \\
\hline Q2 & 0.941130 & 66.536718 & & & \\
\hline Q3 & 0.947279 & 82.259914 & & & \\
\hline Q4 & 0.917377 & 52.716554 & & & \\
\hline \multicolumn{6}{|c|}{ Environmental Concern } \\
\hline $\begin{array}{r}\text { Responsibility o } \\
\text { Consumer }\end{array}$ & & & \multirow{5}{*}{0.970488} & \multirow{5}{*}{0.959093} & \multirow{5}{*}{0.891669} \\
\hline Q1 & 0.897971 & 36.834834 & & & \\
\hline Q2 & 0.974864 & $\begin{array}{c}169.49484 \\
2\end{array}$ & & & \\
\hline Q3 & 0.927150 & 73.322634 & & & \\
\hline Q4 & 0.944864 & $\begin{array}{c}139.49488 \\
2\end{array}$ & & & \\
\hline \multicolumn{3}{|c|}{$\begin{array}{l}\text { Recycling \& Reuse level } \\
\text { of the Consumer }\end{array}$} & \multirow{3}{*}{0.965126} & \multirow{3}{*}{0.927792} & \multirow{3}{*}{0.932602} \\
\hline Q1 & 0.967729 & $\begin{array}{l}157.57485 \\
5\end{array}$ & & & \\
\hline Q2 & 0.963694 & $\begin{array}{c}114.24531 \\
7\end{array}$ & & & \\
\hline \multicolumn{3}{|c|}{$\begin{array}{l}\text { Environmental } \\
\text { Knowledge }\end{array}$} & \multirow{3}{*}{0.852094} & \multirow{3}{*}{0.653886} & \multirow{3}{*}{0.742372} \\
\hline Q1 & 0.877840 & 5.712404 & & & \\
\hline Q2 & 0.845069 & 4.653651 & & & \\
\hline \multicolumn{6}{|c|}{ Government's Role } \\
\hline Investment & & & \multirow{4}{*}{0.912045} & \multirow{4}{*}{0.855413} & \multirow{4}{*}{0.775825} \\
\hline Q1 & 0.916155 & 7.030737 & & & \\
\hline Q2 & 0.840164 & 6.495808 & & & \\
\hline Q3 & 0.884455 & 6.909024 & & & \\
\hline $\begin{array}{r}\text { Establishing Rul } \\
\text { Regulations }\end{array}$ & & & \multirow{4}{*}{0.955693} & \multirow{4}{*}{0.930399} & \\
\hline Q2 & 0.921095 & 47.434533 & & & 0.877923 \\
\hline Q3 & 0.954418 & 89.316049 & & & \\
\hline Q4 & 0.935115 & 67.669996 & & & \\
\hline
\end{tabular}


Source: Survey Data, 2020

\subsection{Structural Model (Inner Model)}

\subsubsection{Assess the level of $R^{2}$ (Coefficient of determination)}

This model R square values of the dependent variable recorded as 0.246 . It is moderate effect of the model. However, based on the results we can conclude that $24.6 \%$ variation of the Purchasing Intention is being clearly explained by the independent variables of the study.

\subsubsection{Assessment of squared $\left(f^{2}\right)$ - Effect Size}

Table 5: Effect of size

\begin{tabular}{|l|c|c|}
\hline \multicolumn{1}{|c|}{ Variables } & $\mathbf{f}^{2}$ Value of PI & Effect Size \\
\hline Product Characteristics & 0.1048 & Small \\
\hline Environmental Concern & 0.0509 & Small \\
\hline Government's Role & 0.0006 & No \\
\hline
\end{tabular}

Source: Survey Data, 2020

\subsubsection{Assess the Predictive Relevance (Q2)}

In this study showed $\mathrm{Q}^{2}=0.0882$ the results of cross validations of $\mathrm{Q} 2$ values for Purchasing Intention records values greater than zero, that means this model considered to have predictive relevance with a small effect $(>0.02)$.

Assess the significance and relevance of the Demographic Factors (Gender, Education \& Income)

Table 6: Demographic Factors relationship testing

\begin{tabular}{|l|c|c|c|}
\hline \multicolumn{1}{|c|}{ Variable } & Chi Square value & P value & Pearson Correlation \\
\hline Gender & 0.218 & 0.147 & -0.103 \\
\hline Education & 0.012 & 0.000 & 0.258 \\
\hline Income & 0.001 & 0.465 & 0.052 \\
\hline
\end{tabular}

Source: Survey Data, 2020 


\subsection{Hypothesis Testing}

Table 7: Hypothesis Testing

\begin{tabular}{|c|l|c|c|c|c|}
\hline Variable & Hypothesis & Relationship & $\begin{array}{c}\text { T Statistics } \\
(\mid \mathbf{O} / \text { STERR } \mid)\end{array}$ & Co-efficient & Results \\
\hline \multirow{4}{*}{$\begin{array}{c}\text { Product } \\
\text { Characteristics }\end{array}$} & \multicolumn{1}{|c|}{ H1 } & PC -> PI & 2.150056 & 0.411112 & Supported \\
\cline { 2 - 6 } & H1a & P <- PC & 7.667636 & 0.750502 & Supported \\
\cline { 2 - 6 } & H1b & Q <- PC & 3.332654 & 0.484535 & Supported \\
\hline \multirow{4}{*}{$\begin{array}{c}\text { Environmental } \\
\text { Concern }\end{array}$} & H2 & ENV -> PI & 0.12108 & 0.039323 & Not Supported \\
\cline { 2 - 6 } & H2a & ENV1 <- ENV & 4.044365 & 0.452317 & Supported \\
\cline { 2 - 6 } & H2b & ENV2 <- ENV & 4.219019 & 0.436251 & Supported \\
\cline { 2 - 6 } & H2c & ENV3 <- ENV & 2.643597 & 0.342318 & Supported \\
\hline \multirow{3}{*}{$\begin{array}{c}\text { Government's } \\
\text { Role }\end{array}$} & H3 & GR -> PI & 0.073786 & 0.026155 & Not Supported \\
\cline { 2 - 6 } & H3a & GR1 <- GR & 0.047497 & 0.223210 & Not Supported \\
\cline { 2 - 6 } & H3b & GR2 <- GR & 2.487158 & 1.019299 & Supported \\
\hline \multirow{3}{*}{$\begin{array}{c}\text { Demographic } \\
\text { Factors }\end{array}$} & Hypothesis & Relationship & P value & Co-efficient & Results \\
\cline { 2 - 6 } & H4a & EDU -> PI & 0.000 & 0.442 & Supported \\
\cline { 2 - 6 } & H4b & INC -> PI & 0.465 & 0.049 & Not Supported \\
\cline { 2 - 6 } & H4c & GEN -> PI & 0.147 & -0.235 & Not Supported \\
\hline
\end{tabular}

Source: Survey Data, 2020

$\boldsymbol{H}$ 1: There is positive relationship between product characteristics on consumer purchase intention towards Green Packaging at 95\% significance level.

- $\quad \boldsymbol{H} \mathbf{1}_{\boldsymbol{a}}$ : There is a positive relationship between prices on product characteristics towards Green Packaging purchasing Intention at 99\% significance level.

- $\quad \boldsymbol{H} \mathbf{1}_{b}$ : There is a positive relationship between qualities on product characteristics towards Green Packaging purchasing Intention at 99\% significance level.

H 2: There is positive relationship between Environmental Concern of the Customers on Purchase Intention towards Green Packaging. But there is no any significant relationship between Purchasing Intention $(t$-stat $=0.121)$

- $\boldsymbol{H} \mathbf{2}_{a}$ : There is a positive relationship between responsibilities of the consumers on environmental concern towards Green Packaging purchasing Intention at 99\% significance level.

- $\quad \boldsymbol{H} \boldsymbol{2}_{b}$ : There is a positive relationship between recycling \& reuse level of the consumer on environmental concern towards Green Packaging purchasing Intention at 99\% significance level.

- $\quad \boldsymbol{H} 2_{c}$ : There is a positive relationship between environmental knowledge on environmental concern towards Green Packaging purchasing Intention at 99\% significance level. 
H 3: There is a positive relationship between Roles of the Government on Consumer Purchase Intention towards Green Packaging. But there is no any significant relationship between Purchasing Intention ( $t$ stat $=0.0737$ )

- $\quad \boldsymbol{H} \mathbf{3}_{a}$ : There is a positive relationship between investments on government's role towards Green Packaging purchasing Intention. However, there is no any significant relationship between Purchasing Intention $(t$-stat $=0.0474)$

- $\quad \boldsymbol{H} 3_{b}$ : There is a positive relationship between establishing rules \& regulations on government's role towards Green Packaging purchasing Intention at 95\% significance level.

\section{Relationship between Roles of the Demographic Factor on Consumer Purchase Intention towards} Green Packaging.

- $\quad \boldsymbol{H} 4_{a}$ : There is a positive significant relationship between education on demographic factors towards Green Purchasing Intention. ( $p$ value $=0.000)$

- $\boldsymbol{H} 4_{b}$ : There is a positive insignificant relationship between income on demographic factors towards Green Packaging purchasing Intention. ( $p$ value $=0.465$ )

- $\quad \boldsymbol{H} \mathbf{4}_{c}$ : There is a negative insignificant relationship between gender on demographic factors towards Green Packaging purchasing Intention. ( $p$ value $=0.235$ )

\section{CONCLUSIONS, RECOMMENDATIONS AND IMPLICATIONS}

\subsection{Conclusion}

Green marketing is a worldwide and broad concept in the world, therefore, consumers are becoming more sensitive in their purchasing behaviors according to the environmental sensitivity. Thus, the present study provides some initial understanding about the importance and impact of green packaging on customer purchasing intention of millennial generation. According to this study identified that all examined independent variables and their sub variables determined positive relationship with Purchasing Intention except Gender(H4c). However, the outcomes represented that no significant effect of Government Role (H3), Environmental Concern (H2), Income (H4b), Gender (H4c) and Investment of Government ( $\mathrm{H} 3 \mathrm{a})$ under the Government Role but other mentioned variables recorded 95\% significant on Purchasing Intention from selected 200 millennial consumers who age between 18 - 35 years. However, Under the ages belong to different categories and more persons are in the age between $22-25$ years and it is $56 \%$ of the total sample and many of respondents consists of majority of females with $68 \%$. Considering collected data many of respondents recorded the highest category $49.5 \%$ spend on FMCG per month Rs. 10,001 - 20,000 which is represent the half of the selected sample proportion. Based on the answers given, majority of the respondents stated that "yes" that means they are aware on 
those type of product while less proportion (34\%) has chosen the option "No" option. Then the study identified that younger generation has an awareness and knowledge about ecological behavior. When considering demographic factors relation with Green Purchasing, then education and income reported positive relationship but gender recorded negative relationship between green purchasing intention among youngers in Gampaha District. As well as only education show significant relationship out of these three demographic factors so that, gender and income reported insignificant with ecological purchasing pattern. This finding is somewhat contradictory with the literature where in literature it was found that there is a relationship between gender, education and income and purchase intention. But this was not proved from the findings of the in this research.

\subsection{Recommendations}

These conclusions would be convenient for Fast Moving Consumer Goods businesses which are determined in Sri Lankan economy and business field to enhancement their profits and market share further by satisfying the consumers' needs and wants, although focusing newly trending areas in the business field which are emerging accessible the international market place. Considering the outcomes of the study, government should implement these ecological behaviors among student children because they have to more knowledge about environmentally friendly ways and ecological behaviors, it's very good investment to the future. So that, government can debate with appropriate authorities and add environmental and conservation problems as a subject to the syllabus in schools.

\subsection{Implications}

The major implications of this study formed awareness into buying intention towards ecological packaging which can be used by FMCG businesses in Sri Lanka. With the intention of motivate the Sri Lankan customers to involve with the eco-friendly product buying decisions, so that the manner emphasize the emotional outlook of the product benefits and also usage. These results have certain implications for both marketers as well as national level policy makers in Sri Lanka. Specifically, Government have to implement new rules and regulations furthermore because this study mainly identified younger generation abler to protect the environment and also, they like to engage with new concepts under the sustainability of the economy. 


\section{REFERENCES}

Abdul-Muhmin, A. (2007). Explaining consumers? willingness to be environmentally friendly. International Journal of Consumer Studies, , 31(3), , pp.237-247.

Ahmed, R., Parmar, V. and Amin, M. (2014). Impact of Product Packaging on Consumer's Buying Behavior. European Journal of Scientific Research., pp 21-29.

Amyx, D., Dejong, P., Lin , S., Chakraborty, G., \& Wiener, J. (1994). Influencers of purchase intentions for ecologically safe products :An exploratory study. (C.W.and Smith.D.C, Ed.) Marketing Theory and Applications Proceedings of the 1994 AMA Winter Educators' Conference, pp 341-347.

Anderson, T. and Cunningham, W. (1972). The socially conscious consumer. Journal of marketing, 36, pp.23 - 31 .

Bamberg, S. (2012). How does environmental concern influence specific environmentally related behaviors? A new answer to an old question. Journal of Environmental Psychology, 23(1), pp.21-32.

Bang, H., Ellinger, A.E., Hadjimarcou, J. and Traichal, P.A. (2000). "Consumer concern, knowledge, belief, and attitude toward renewable energy: an application of the reasoned action theory". Psychology and Marketing, Vol. 17(No. 1), pp. 6-26.

Bonini, S. and Oppenhiem, J. (2008). Cultivating the Green Consumer. In: Stanford Social Innovation 10TH Review Anniversary., pp.1-10.

Chan, R. (2001). Determinants of Chinese consumers' green purchase behavior. Psychology and Marketing,, 18(4),, pp.389-413.

Chan.R.Y.K \& Yam,E. (1995). Green movement in a newly industrializing area : A survey on the attitudes and behavior of the Hong Kong citizens. Journal of community and Apl=plied Social Psychology, 5,273-284.

Chen, T. and Chai, L. (2010). Attitude towards the Environment and Green Products: Consumers` Perspective. Management Science and Engineering,, 4, pp.27-39.

Chen, Y. and Chang, C. (2012). Enhance green purchase intentions. Management Decision, 50(3), pp.502-520.

Chen, Y.-S. Chai, L.-B., \& Wen, C.-T. (2006). The Influence of Green Innovation Performance on Cor porate Advantage in Taiwan. Journal of Business Ethics, Vol 67(4), pp 331-339.

Chukwuma, C. S. (1998). Environmental issues and our chemical world- The need for a multidimensional approach in environmental safety, health and management. Environmental Management and Health, 9(3),pp 136-43.

Chyong, H., Phang, G., Hasan, H. and Buncha, M. (2006). Going green: A study of consumers' willingness to pay for green products in Kota Kinabalu. International Journal of Business and Society, , pp.40-54.

D’Souza, C., Taghian, M., \& Khosla, R. (2007). Journal of Targeting, Measurement and Analysis for Marketing. Examination of environmental beliefs and its impact on the influence of price, quality and demographic characteristics with respect to green purchase intention., Vol 15(2), pp 69-78.

Department of Census and Statistics (2019). Distict Statistical HandBook. Retrieved from [online] Available at: http://www.statistics.gov.lk/DistrictStatHBook.asp 8.

Dettmann, R. and Dimitri, C. (2007). "Who’s buying organic vegetables? Demographic characteristics of US consumers". Journal of Food Distribution Research, pp. 49-62.

Dummett, K. (2006). Drivers for corporate environmental responsibility. Environment, Development and Sustainability, 8, pp.375-389.

Eagly, A. (1987). Sex differences in social behavior. A social-role interpretation, pp. 6-26. 
Follows, Scott, B., \& David , J. (2000). "Environmentally Responsible Purchase Behavior: A Test of a Consumer.”. European Journal of Marketing, 34 (5/6), pp 723-746.

Fredriksson, Per, G. and Mani, M. (2002). The Rule of Law and the Pattern of Environmental Protection. IMF Working Paper. International Journal of Business and Society, pp 20-35.

Fryxell, G., \& Lo, C. (2003). The influence of environmental knowledge and values on managerial behaviors on behalf of the environment: An empirical examination of managers in China. Journal of Business Ethics, Vol, 46, pp. 4559.

Gan, C. (2008). Consumer purchasing behavior towards green products in New Zealand. Innovative Marketing, 4(1), pp 92-102.

Global Green Packaging Market Analysis. (2018). Retrieved from www.grandviewresearch.com

Global Web Index -Consumers Going Green . (2018). globalWebindex. Retrieved from www.globalwebindex.com

Grob, A. (1995). A Structural Model Of Environmental Attitudes And Behaviour. Journal of Environmental Psychology, 15, pp.209-220.

Harris, P. G. (2006). Environmental perspectives and behavior in China: Synopsis and bibliography. Environment and Behavior, 38(1), 5-21.

Hoffmann, S. and Schlicht, J. (2013). "The impact of different types of concernment on the consumption of organic food",. International Journal of Consumer Studies, , vol. 37, no. 6, pp. 625-633.

Irawan, R. and Darmayanti, D. (2012). The influence factors of green purchasing behavior: A study of university students in Jakarta. Retrieved Feb 23, 2013, from [online] Available at: http://www. wbiconpro.com/517\%20$\%$ 20Dahlia.pdf

Jain, S. and Kaur, G. (2004). Green Marketing: An Attitudinal and Behavioural Analysis of Indian Consumers. Global Business Review, 5(2), pp.187-205.

Jolibert, A., \& Baumgartner, G. (1981). Toward a definition of the consumerist segment in France. Journal of Consumer Research, Vol 8 , No 1, June , pp 114-117.

Kalafatis, S., Pollard, M., East, R., \& Tsogas, M. (1999). Green marketing and Ajzen's theory of planned behaviour: a cross-market examination. Journal of Consumer Marketing, 16(5), pp.441-460.

Kaman .L. (2008). Gender differences in Hong Kong adolescent consumers' green purchasing behavior. Journal of Consumer Marketing, 26, 87-96. doi:10.1108/07363760910940456

Keller, K. (2001). Building customer-based brand equity: creating brand resonance requires carefully sequenced brand-building efforts. Marketing Management, 10(2), pp.15-19.

Kinner, T.C. and Taylor, J.R. (1973). "The effect of ecological concern on brand perceptions". Journal of Marketing Research, Vol. 10 No. 2, pp. 192-197.

Laroche, M., Bergeron, J., \& Barbaro-Forleo, G. (2001). Targeting consumers who are willing to pay more for environmentally friendly products. Journal of Consumer Marketing, 18(6), pp.503-520.

Lehner, M., Popwer, K. and Mont, O. (2011). Public perceptions and values and perceptions of importance for Sustainable Consumption policy. In: Sustainable Consumption Conference 2011 'Sustainable Consumption Towards Action and Impact'., pp.23 - 31.

Li ,J.J. \& Su ,C. (2007). How face influences consumption : a comparative study of American and Chinese consumer. International journal of Marketing Resaerch, Vol 49, No 2 , pp 237-256. 
Mahmoud, M., Mojtaba, S., Reza, G., Roozbeh, H., Omid, F., \& Dariush, J. (2011). "Brand Equity Determinants in Educational Industry: A study of large universities of Malaysia". IJCRB journal, November issue, Vol. 3, No 7, p $769-781$.

Makeower, J. (2009). Strategies for the Green Economy:Opportunities and Challenges in the New World of Business. NewYork: McGraw-Hill ,pp 28.

Mani, M., \& Fredriksson, G. (2002). The rule of law and the pattern of environmental protection. IMF Working Paper, Vol 2(49), PP 1-25.

Mansaray, A., \& Abijoye, J. O. (1998). nvironmental knowledge, attitudes and behavior in Dutch secondary school. Journal of Environmental Education, 30(2) PP 4-11.

Mostafa, M. (2007). Gender differences in Egyptian consumers' green purchase behaviour: the effects of environmental knowledge, concern and attitude. International Journal of Consumer Studies, 31, pp.220-229

Oakland, J., \& Porter, L. (2004). Quality in the 21st century - the foundation. Quality World, 30(1), pp.10-14.

Ottman, J. (2003). Sometimes consumers will pay more to go green. Marketing News (July 6), pp 16.

Ottman, J., Stafford,, E., \& Hartman, C. (2006). Avoiding green marketing myopia: ways to improve consumer appeal for environmentally preferable products. Environment, Vol 48 NO. 5, pp 22-36.

Ottman, J.A. and Reilly, W.R. . (1998). 'Sometimes consumers will pay more to go green'. Green Marketing: Opportunity for Innovation, pp 740-751.

Paettie, K. \& Crane, A. (2005). Green marketing: legend, myth, farce or prophecy? Qualitative Market Research: An International Journal, 8 (4), pp. 357-370.

Paul, J. and Rana, J. (2012). Consumer behavior and purchase intention for organic food. Journal of Consumer Marketing, 29(6), pp.412-422.

Pavan, M. P. (2010). Golden Rule of Green Marketing. Green Marketing In India: Emerging Opportunities and Challenges, Vol 3, pp.6.

Peck, S., \& Gibson, R. (2000). Pushing the Revolution. Alternatives Journal, 26(1), pp.9-11.

Polonsky. M. J. . (1994). “An Introduction to Green Marketing”. Electronic Green Journal, Vol, 1 No. 2, pp. 1-10.

Powell, G., \& Graves, L. (2003). Green Behavior and norms. Women and men in management, pp 151-160.

Rayapura, A. (2014). New Nielsen Study Says Consumers Are Ready to Pay More for Social Responsibility. Retrieved from

http://www.sustainablebrands.com/newsandviews/stakeholder_trends_insights/aarthi_rayapura/new_nielsen_stu dy_says_consumers_are_ready [Accessed 1 Nov. 2015].

Roberts, J. (1996). Green consumers in the 1990s: Profi le and implications for advertising. Journal of Business Research, 36 (3) , 217 - 231.

Roberts, J. and Bacon, D. (1997). Exploring the Subtle Relationships between Environmental Concern and Ecologically Conscious Consumer Behavior . Journal of Business Research, 40(1), pp.79-89.

Rothstein, B. (2011). "The Quality of government. Corruption, Social Trust, and Inequalityll in International Perspective". International Journal, pp 9-15.

Samarasinghe.G.D. \& Samarasinghe D.S.R. (2013). Green decisions: consumers' environmental beliefs and green purchasing behaviour in Sri Lankan context. Int. J. Innovation and Sustainable Development, Vol. 7, No. 2, 2013, pp 172-184. 
Schultz, P. W., \& Zeleny, L. C. (2000). Promoting environmentalism. The Journal of Social Issues, 56, pp $443-457$.

Soonthonsmai, V. (2001). Environmental or green marketing as global competitive edge: Concept, synthesis, and implication. In: In EABR (Business) and ETLC (Teaching) Conference Proceeding.

Straughan, R.D. and Robberts, J.A. (1999). Environmental segmentation alternatives: A look at green consumer behavior in the new millennium. Journal of Consumer Marketing, 16(6), 558-75.

Wanninayake, W., \& Randiwela, P. (2008). Consumer Attractiveness Towards Green Products of Fmcg Sector: An Empirical Study. 2008 Oxford Business \&Economics Conference Program.

Wood, D. (1991). Corporate social performance revisited. Academy of Management Review, 16(4), pp.691-718.

Xiao, C., \& Hong, D. (2010). "Gender differences in environmental behaviors in China". Population and Environment, 32(1), pp.88-104.

Yeung, S. (2004). Teaching Approaches in Geography and Students? Environmental Attitudes. The Environmentalist, 24(2), pp.101-117.

Zen, I., Noor, Z., \& Yusuf, R. (2014). The profiles of household solid waste recyclers and non-recyclers in Kuala Lumpur, Malaysia. Habitat International, 42, pp.83-89.

Zhang, G. \& Zhao, Z. (2012). Green Packaging Management of Logistics Enterprises. 2012 International Conference on Applied Physics and Industrial Engineering, 24, 900-905. doi:doi:10.1016/j.phpro.2012.02.135 